Preliminary Program

WESTERN FINANCE ASSOCIATION ANNUAL MEETING

Las Vegas, Nevada

June $9-11,1974$

Monday, June 10

$8: 15$ - 9:50 A.M.

I. NEW YORK STOCK EXCHANGE VERSUS LAS VEGAS

Chairman: Seha Tinic, University of Alberta

Papers: James J. Noel, Nevada Gaming Control Board

"Profitability and Behavior of the Gaming Industry Relative to the stock Market"

Jeffrey F. Jaffe, University of Pennsylvania

"The value of Information in Speculative Markets"

Bernell Stone, Cornell University

"Systematic Interest Rate Risk in a Two-Index Model of Return"

Discussants: Steve Beveridge, University of Alberta

Earl Keller, University of Michigan

Robert Korkie, University of Alberta

II. FINANCIAL INSTITUTIONS AND MARKETS

Chairman: Richard v. Cotter, University of Nevada, Reno

Papers: $\quad$ Peter S. Rose and Donald Fraser, Texas A \& M University

"Banking Markets and the Measurement of Competition"

Yair Orgler, Federal Deposit Insurance Corporation

"Capital Adequacy of Failed Banks"

Edwin P. Mampe, Jr., Atomic Energy Commission

"Efficiency in the Third Market: INASDAQ"

Discussants: Vincent P. Apilado, Arizona State University

Stephen $H$. Archer, Willamette University

Paul M. Horvitz, Federal Deposit Insurance Corporation

$10: 00-11: 45$ A.M.

III. RECENT MONETARY POLICY (Joint session with the Western Economic Association)

Chairman: George G. Kaufman, University of Oregon

Papers :

"The View from the Fed"

Joel Segall, U. S. Department of Labor

"The View from the Government"

Edward J. Kane, Ohio State University

"The View from Academe"

Discussants: Maurice Mann, Federal Home Loan Bank of San Francisco

Lyle Kalish, California State University, Fullerton 
IV. CORPORATION FINANCE

Chairman: Robert H. Litzenberger, Stanford University

Papers: $\quad$ Roger P. Bey, University of Missouri

"Intertemporal Cash Flows in Capital Budgeting Decisions"

o. Maurcee Joy and F. Hutton Barron, University of Kansas

"Behavior Risk Constraints in Capital Budgeting"

Milford s. Tysseland, University of Florida

"Price Level Depreciation in Public Utility Pricing"

Discussants: Charles A. D'Ambrosio, University of Washington

John P. Herzog, Simon Fraser University

Ramon E. Johnson, University of Utah

$12: 30$ - 2:00 P.M. (Luncheon)

PRESIDENTIAL COMMENTS AND BUSINESS UAEETING

President James E. Wert, University of Arizona

$3: 45$ - 5:15 P.M.

V. TEACHING OF INVESTMENTS: ROUNDTABLE

Chairman: Michael H. Hopewell, University of Oregon

Panelists: Keith V. Smith and David K. Eiteman, University of California at Los Angeles

George A. Christy, North Texas State University

Richard R. West, University of Oregon

VI. INTERNATIONAL AND REAL ESTATE FINANCE

Chairman: Edward Gordon, Claremont Graduate School

Papers: $\quad$ Rolf Mirus, University of Alberta

"The West German Capital Market"

Larry Merville, University of Texas, Dallas

"Transfer Pricing for Multinational Firms"

Robert C. Radcliffe, University of Florida

"Real Estate Investment Trust Performance"

Discussants: Michael Keran, Federal Reserve Bank of San Francisco Miles Livingston, University of Wisconsin, Milwaukee

w. Giles Melion, Rutgers University 
Tuesday, June 11

8:00 - 10:15 A.M.

VII. REFORM OF FINANCIAL INSTITUTIONS AND MARKETS: A PROGRESS EVALUATION

Chairman: Peter S. Rose, Texas A \& M University

Papers: Almarin Phillips, University of Pennsylvania

"Financial Institutions"

William E. Gibson, Brookings Institution

"Financial Institutions"

Donald E. Farrar, University of California at Los Angeles

"Financial Markets"

Morris Mendelson, University of Pennsylvania

"Financial Markets"

Discussants: William C. Freund, New York Stock Exchange

Frank K. Reilly, University of Wyoming

J. Fred Weston, University of California at Los Angeles

$8: 30$ - 10:15 A.M.

VIII. INVESTMENTS - EQUITIES: I

Chairman: Michael Brennan, University of British Columbia

Papers: $\quad$ Robert Hamada, University of Chicago

"Capital Asset Pricing"

T. J. Nantell, University of Michigan, and J. G. Green, Michigan State University

"Portfolio Theory and Capital Market Theory"

John Emery and Allen A. Abrahamson, University of Arizona

"Risk and Price Distributions"

Discussants: Michael Brennan, University of British Columbia

James Bicksler, Rutgers University

A. Blaine Huntsman, University of Utah

$10: 30$ A.M. - 12:00 Noon

IX. FINANCING THE MULTINATIONAL FIRM

Chairman: David K. Eiteman, University of California at Los Angeles

Papers: Rita M. Rodriguez, Harvard University

"Foreign Exchange Management of the U. S. Multinational Company"

Ruediger Naumann-Etienne, University of Michigan

"Optimizing Financial Decisions in a Cost of Capital Framework"

Arthur I. Stonehill, Oregon State University

"P: Ifitability as a Determinant of Corporate Financial structures:

Ar International Study"

Discussants: Robert S. Einzig, Transamerica Corporation

Cheukuen Kwan, University of New Mexico

Dale A. Vorderlandwehr, American Graduate School of International Business 
X. INVESTMENTS - EQUITIES: II

Chairman: Robert C. Higgins, University of Washington

Papers: $\quad$ Arthur E. Gooding, University of Southern California

"Investor Perceptions and Demographic Profiles"

Manak C. Gupta, Temple University

"Performance of the Mutual Fund Industry: A Reconsideration"

Robert $\mathrm{H}$. White, University of British Columbia

"The Determinants of Systematic Risk"

Discussants: Peter 0 . Dietz, University of Oregon

Robert C. Higgins, University of Washington

Nancy Jacob, University of Washington

2:15 - 3:45 P.M.

XI. INVESTMENTS - BONDS

Chairman: James E. Wert, University of Arizona

Papers: $\quad$ Pao Lun Cheng, Simon Fraser University

"Valuation of Corporate Bonds"

Ronald Forbes, Alan Frankle, and Arthur Hierl, State University of New York at Albany

"Homogeneous Risk Classes for Municipal Bonds"

Gordon S. Roberts, Babson College

"The Term Structure of Interest Rates: A Micro Approach"

Discussants: George H. Hempel, Washington University

John P. Shelton, University of California at Los Angeles

James E. Wert, University of Arizona

XII. STUDENT AWARD

Chairman: Lester Strickler, Oregon State University

4:00 - 5:00 P.M.

SPECIAL SESSION (Western Economic Association)

Paul A. Samuelson, Massachusetts Institute of Technology

\section{PROGRAM COMMITTEE}

George G. Kaufman, University of Oregon, Chairman Michael Brennan, University of British Columbia David $K$. Eiteman, UCLA

Robert C. Higgins, University of Washington

Michael H. Hopewell, University of Oregon

Nancy Jacob, University of Washington

Peter S. Rose, Texas A \& $M$

Seha Tinic, University of Alberta

James E. Wert, University of Arizona 